\title{
The Contributions of Paul Ehrlich to Pharmacology: A Tribute on the Occasion of the Centenary of His Nobel Prize
}

\author{
Fèlix Bosch ${ }^{a, b} \quad$ Laia Rosich $^{a}$ \\ a Esteve Foundation, and ${ }^{b}$ Department of Experimental and Health Sciences, Universitat Pompeu Fabra, \\ Barcelona, Spain
}

\section{Key Words}

Paul Ehrlich · Arsenicals • Arsphenamine - Dyes ·

Animal experimentation $\cdot$ Therapeutic pharmacology •

Chemotherapy $\cdot$ Syphilis $\cdot$ Side-chain theory

\begin{abstract}
On the centenary of Paul Ehrlich's Nobel Prize, this German researcher deserves to be remembered as a pioneer in a large number of scientific disciplines. As a result of his enthusiasm and scientific abilities, dedication, and contacts with other scientists of his time, he was able to make countless contributions in fields as diverse as histology, haematology, immunology, oncology, microbiology and pharmacology, among others. Although the Swedish award was meant to recognize the standardization of the manufacture of antidiphtheria serum, it was the discovery of arsphenamine (Salvarsan) for the treatment of syphilis which won him wider international acclaim. From a pharmacological perspective, Ehrlich's outstanding contributions include dissemination of the 'magic bullet' concept for the synthesis of antibacterials, introduction of concepts such as chemoreceptor and chemotherapy, and linking the chemical structure of compounds to their pharmacological activity. These achievements took place within the framework he established for the transition from experimental pharmacology to therapeutic pharmacology. He introduced a modern research system based on the synthesis of multiple chemical structures
\end{abstract}

for pharmacological screening in animal models of disease states. These contributions were undoubtedly decisive in propitiating the wider development of antibiotics decades later. For these reasons, it is fitting to mark the 100th anniversary of the Nobel Prize awarded to this great scientist by commemorating the importance of his contributions to the advance of pharmacology.

Copyright $\odot 2008$ S. Karger AG, Basel

\section{Introduction}

Paul Ehrlich (1854-1915) (fig. 1) and the Russian immunologist Ilya Mechnikov (1845-1916), who discovered phagocytosis, received the Nobel Prize for Physiology or Medicine in 1908 [1]. On the centenary of this event, it is fitting to commemorate Paul Ehrlich's life and work not only because of this distinction, but also because of his many other contributions, particularly in the development of applied pharmacology - an area which could be termed 'therapeutic pharmacology' - in the early twentieth century.

Contributions to the field of toxicology by Mateu Bonaventura Orfila (1787-1853) along with the physiological experiments of François Magendie (1783-1855) and his main disciple, Claude Bernard (1813-1878), were fundamental in the origin of experimental pharmacology. The creation of the first institute of pharmacology is 


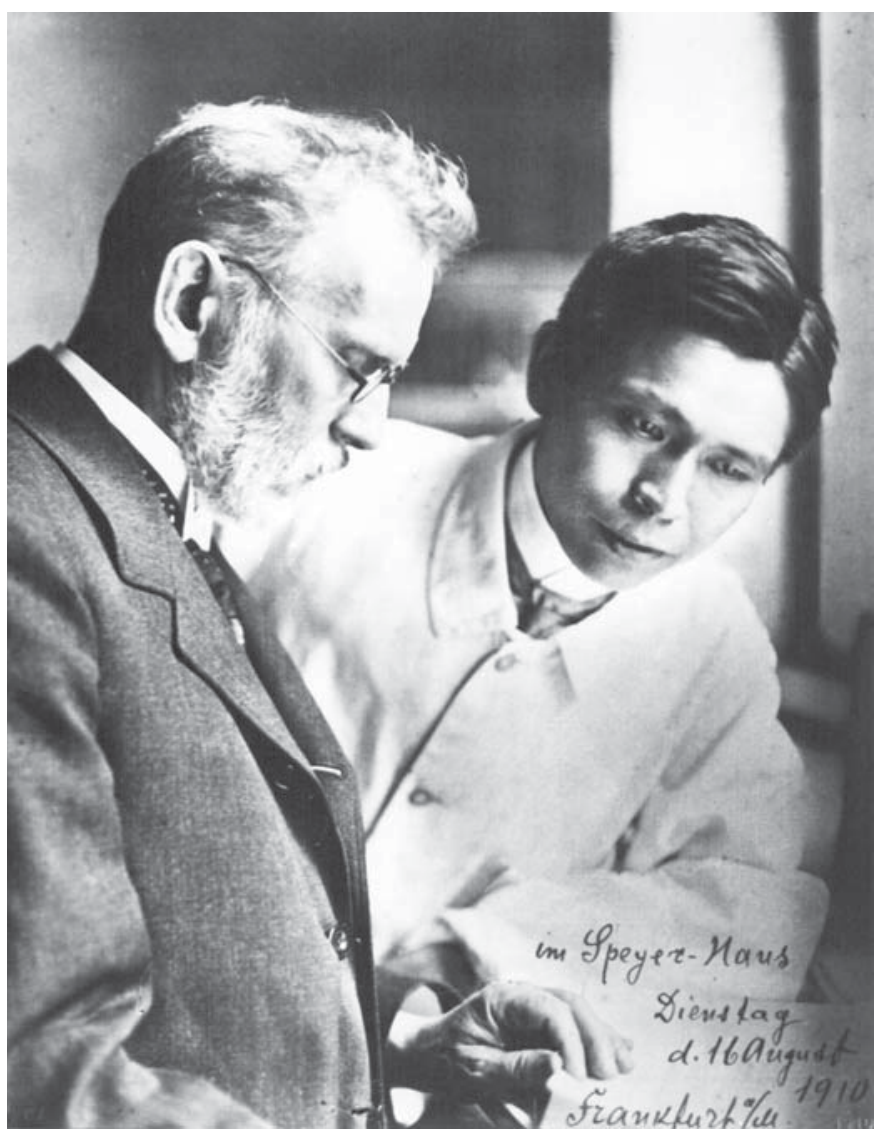

Fig. 1. Paul Ehrlich (1854-1915) and Sahachiro Hata (1873-1938), Frankfurt 1910. Their partnership led to the discovery of arsphenamine (reprinted courtesy of the Paul-Ehrlich-Institut, Langen, Germany) [10].

credited to the German scientist Rudolf Buchheim (18201879), considered the founder of modern pharmacology. Together with the contributions of his disciple Oswald Schmiedeberg (1838-1921), these achievements formed the basis for advances in pharmacological research [2].

Experimental pharmacology, with its roots in the nineteenth century, would begin to bear fruit at the end of this century and throughout the twentieth century. Paul Ehrlich stood out because he went beyond the study of drugs and toxic substances: new drugs needed to be synthesized for specific targets. Ehrlich contributed to the transition from experimental pharmacology to pharmacological therapeutics, which in turn led to the birth of chemotherapy [3]. Ehrlich believed that experimental therapeutics should aim to reproduce diseases in animals and proceed from there to the scientific evaluation of drugs, rather than being restricted to studies of healthy animals or tissues, as had been the practice until then in experimental pharmacology. Infectious diseases were one example of this approach. Moreover, Ehrlich was to establish the basic procedures for chemical synthesis aimed at obtaining new drugs. The first step, according to Ehrlich's approach, was to synthesize a large number of chemical structures which might be related to varying degrees. This was followed by pharmacological screening to evaluate their efficacy. In order to obtain safer drugs, the structure of toxic drugs was modified or new chemical compounds were synthesized. This systematic approach was of key importance in obtaining drugs that were introduced in the early twentieth century [2].

\section{Early Work and Initial Challenges}

Paul Ehrlich was born on 14 March 1854, in Strehlen (a town in the Silesia province of Germany, now part of Poland). Of Jewish parentage, he was a cousin of the renowned bacteriologist Carl Weigert (1845-1904), who played an important role as his mentor. It is likely that Weigert was one of the first important scientists of that period who had a decisive influence on Ehrlich's career, along with many others with whom Ehrlich was to work with later in life (table 1). Ehrlich studied medicine at the universities of Breslau, Strassburg and Freiburg between 1872 and 1877, and obtained his degree in medicine in Leipzig in 1878 . He was not an outstanding student, because he was obsessed with tissue staining, as one of his professors recalled when he introduced Ehrlich to Robert Koch (1843-1910) (table 1): 'That is little Ehrlich. He is very good at staining, but he will never pass his examinations' $[4,5]$. Ehrlich's doctoral dissertation dealt with theoretical and practical aspects of histological stains, and he experimented with the recently discovered aniline-derived dyes [6-10]. Upon observing that the uptake of different dyes varied in different tissues, he concluded that strong affinities must exist between biological structures and the stain applied. He was thus able to demonstrate that methylene blue showed a marked affinity for the nervous system, even when used in live animals [4, 6, 11-13]. This work can be considered the first steps in his scientific career - an advance which was to point the way toward other important scientific contributions detailed below, and summarized chronologically in figure 2 .

His contributions to histology carried through to the field of haematology, where he discovered mast cells with histochemical techniques, and distinguished leukocytes from neutrophils, basophils and eosinophils. He demon- 
Table 1. Some scientists active in Paul Ehrlich's time who were involved in his discoveries and main contributions $[2,6,9,17]$

Robert Koch (1843-1910)

Considered the founder of bacteriology, Koch discovered the causal agent of anthrax (1876), the tuberculosis bacillus (1882) and the cholera vibrion (1883), and formulated Koch's postulates to establish the etiology of tuberculosis. He received the Nobel Prize for Physiology or Medicine in 1905. Ehrlich earned Koch's praise by improving the staining method for mycobacteria, received his support, and accepted the post of director of the tuberculosis department at the Moabit Hospital in Berlin. He remained faithful to Koch despite the harsh criticism he received when it was shown that tuberculin was not an effective treatment for tuberculosis. In 1891, Ehrlich was invited to the Institute for Infectious Diseases in Berlin, then under Koch's direction - a move that led to his work with Emil von Behring

Karl Weigert (1845-1904)

An eminent pathologist and pioneer in aniline dye staining, Weigert was the first to detect bacteria in humans (1875). He obtained stains for the myelin sheath (1884), and discovered the pathological anatomy of Bright's glomerulonephritis (1879) and myocardial infarction (1880). He was the first to find a practical use for the microtome. As Ehrlich's cousin and the colleague who first awakened his interest in dyestuffs, his influence on Ehrlich's career was strong

John Newport Langley (1852-1925)

A British physiologist, Langley established the concept of the autonomous nervous system, coined the term 'parasympathetic', and defined the concepts of presynaptic and postsynaptic fibre. He investigated the action of several alkaloids (such as nicotine, pilocarpine, curare and adrenaline) on muscle activity and nerve functions. His ideas contributed to the receptor theory and convinced Ehrlich of the existence of chemoreceptors

Emil von Behring (1854-1917)

The discovery in 1980 of diphtheria and tetanus antitoxins, with the bacteriologist Shibasaburo Kitasato (1890), marked the birth of serum therapy. Joint work by Ehrlich and von Behring under Koch's direction led to the standardization of antidiphtheria serum and its practical applications. However, greater importance was given to von Behring's contribution to the theory of immunization via his discovery of passive immunization, which won him the Nobel Prize for Physiology or Medicine in 1901

\section{Sahachiro Hata (1873-1938)}

Experimental work in rabbits by this Japanese bacteriologist took place at Kitasato's Institute for the Study of Infectious Diseases in Tokyo. In 1909, he moved to the Royal Institute for Experimental Therapy in Frankfurt, where Ehrlich asked him to reassess all the arsenic derivatives synthesized until then. Hata found that arsphenamine was a truly effective antisyphilitic

Alfred Bertheim (1879-1914)

An organic chemist, Bertheim began to work with Ehrlich in 1906 at the Georg-Speyer-Haus in Frankfurt. He elucidated the structure of Atoxyl and synthesized countless derivatives (including arsphenamine) in the course of work aimed at improving the drug's therapeutic efficacy

The Contributions of Paul Ehrlich to Pharmacology strated that the morphology of blood cells was much more varied than had been assumed, and endowed haematology with a solid cytogenetic basis $[13,14]$.

In 1882, Robert Koch announced the discovery of the causal agent of tuberculosis to the Berlin Society for Physiology. Among those present was Ehrlich, who soon realized that the staining method Koch used could be improved upon. Shortly thereafter, Ehrlich developed a new staining protocol that earned praise from Koch himself. The changes Ehrlich introduced later formed the basis for the current Ziehl-Neelsen acid-fast staining used for mycobacteria [12].

Thus staining methods, conceived as tools to obtain results with clinical applications, became the focus of his interest during the period from 1878 to 1887, when Ehrlich worked at the Charite Hospital in Berlin under the clinical direction of Friedrich Theodor Frerichs (18191885). His experimental work resulted in numerous diagnostic methods, some of which still remain in use. For example, with the diazo reaction (Ehrlich reagent) he was the first to detect the presence of bilirubin in the urine of patients with jaundice. However, his scientific career was disrupted in 1888 when Ehrlich was infected by the Koch bacillus, contracted in the course of his laboratory work. To recover from his pulmonary tuberculosis, he travelled to Egypt and southern European countries with his wife Hedwig Pinkus (1864-1948), whom he had married in 1883 and with whom he had 2 daughters. After 2 years, Ehrlich returned home to Berlin, and initiated a new period in his research career, this time in the field of immunology $[10,12]$.

\section{Contributions to Immunology}

In 1890, Emil Adolf von Behring (1854-1917) (table 1) and Shibasaburo Kitasato (1852-1931) published their discovery of tetanus and diphtheria antitoxins. They demonstrated that the administration of gradually increasing doses of tetanus or diphtheria toxoids in animals stimulated the production of antitoxins, and that these compounds, produced in live animals, were able to immunize other animals. However, there were considerable problems with quality control during the production of these sera. At Koch's invitation as director of the recently founded Institute for Infectious Diseases in Berlin - now known as the Robert Koch Institute - between 1890 and 1895, Ehrlich had the opportunity to work with von Behring on the standardizing of the antidiphtheria serum production process. In 1891, Ehrlich was able to develop 


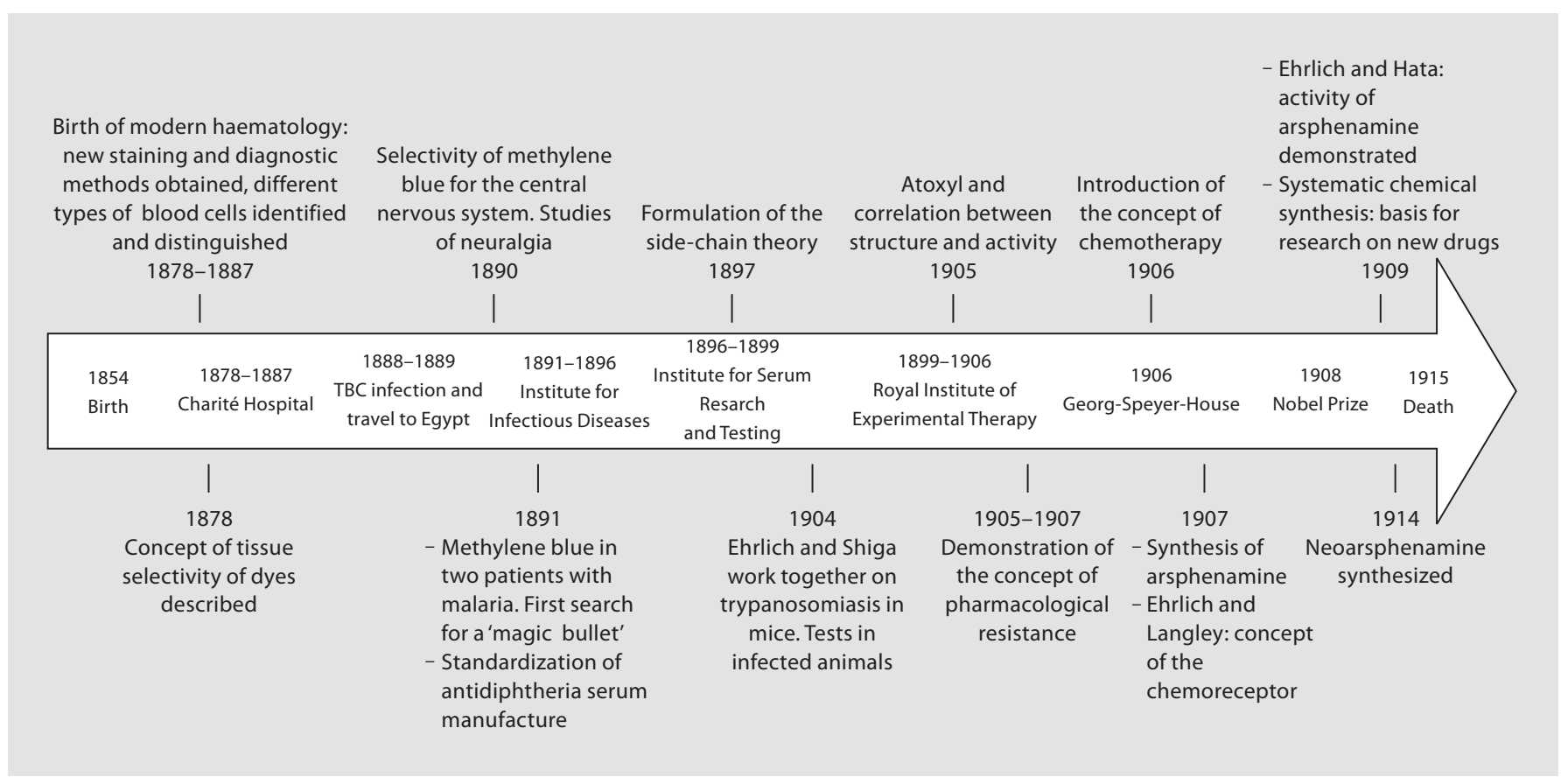

Fig. 2. Chronology of Paul Ehrlich's most important scientific contributions.

effective immunization protocols, and proposed the use of horses for the commercial production of the serum. Soon Ehrlich was placed at the head of the new State Institute for Serum Research and Serum Testing in Berlin (1896), which was later moved to its permanent location in Frankfurt $[10,13]$. The Institute was created to preserve standard preparations, devise new, more accurate methods of determining the effectiveness of sera, and study the complex relations which govern the neutralization of toxins by antitoxins [15].

Von Behring received the first Nobel Prize for Medicine in 1901 as the principal discoverer of serum therapy, when Ehrlich was also a firm candidate for the award [16]. However, it was not until 7 years later when the Swedish academy recognized Ehrlich's contribution in adapting this therapy to actual medical application by means of what is now called biological standardization $[1,15]$.

With the aim of proposing a plausible explanation for the process of immunity, it was in 1897 when Ehrlich formulated his 'side-chain theory', which became the basis for his immunological research at the time. This theory postulated that cells present on their surface a set of sidechains to which Ehrlich attributed functions related with the assimilation of metabolic products. A side-chain from a given cell might have, by simple coincidence, a molecu- lar structure that allowed it to bind with a specific toxin corresponding to diphtheria, tetanus, or some other microorganism. This strictly specific binding between the toxin and the side-chain, in a manner similar to the 'lockand-key' model for enzymes and their substrates described in 1894 by Hermann Emil Fischer (1852-1919), would mean the cell lost its normal function, a phenomenon which in turn would trigger the production of additional side-chains. A large part of these newly produced excess side-chains would be released into the blood stream, where they would act as antibodies or antitoxins upon binding to the toxin present in the blood, and would thus prevent the toxin from binding to other cells in the organism. Thus a small amount of toxin could produce a large amount of antitoxin able to neutralize the toxin's own effect [13].

In 1900, Ehrlich introduced the term 'receptor' as a substitute for the term 'receptive side-chain'. This idea led to a more functional concept that could be applied to the field of pharmacology. John Newport Langley (18521925) (table 1), who studied the effect of alkaloids on muscle cells, proposed the existence of receptors that could be blocked by antagonists or activated through the action of agonists. Although they came from very different research backgrounds, the interaction between Ehr- 
lich's and Langley's thinking was highly productive. Together they developed the receptor theory and extended the concept of the receptor to 'chemoreceptors' to describe the interaction between drugs and cells. Thus the side-chain theory, although not entirely accurate, gave rise to concepts which were to become basic tenets in immunology $[6,13,17]$.

In addition to the side-chain and receptor theory, Ehrlich also established the concepts of active and passive immunity, as well as the mechanisms of transmission of immunity from mother to fetus. However, he was not without detractors who criticized him for his excessively lively imagination and lack of self-criticism. He himself compared his side-chain theory to the cellular theory of Rudolf Virchow (1821-1902), which had also met resistance initially. After 1901, Ehrlich focussed his interests on the field of cancer research, and 3 years later began to study trypanosomal infections - a line of work which was to lead to the introduction of chemotherapy [10].

\section{Structure-Activity Relationships: The Case of Arsenicals}

In this new stage of his scientific activities, Ehrlich's interest returned to a hypothesis formulated during research for his doctorate: the need to study the relationship between the chemical composition of drugs and their mode of action in the organism. His aim, which recalled the paracelsian ideal, was to discover a therapia sterilisans magna, in other words, a treatment which could, in a single dose, destroy all microorganisms in the infected organism $[11,18]$. In the words of Ehrlich, the optimal agents would combine high parasitotropism with low organotropism [16]. Selective drugs were needed which, like antitoxins aimed specifically at their corresponding toxins, would have affinity for pathogens and act as 'magic bullets' without affecting the host's cells $[13,14,19]$.

In fact, the search for such magic bullets had commenced in 1891, when Ehrlich began to work in the field of chemotherapy by studying the antimalarial effect of methylene blue. Although he was able to cure 2 patients with some success, this therapy was not superior to quinine, then in wide use. However, his small success was decisive in his scientific career in the field of modern chemotherapy. Ehrlich concluded that methylene blue not only had clear affinity for the parasite, but also showed low toxicity for the patient $[12,15]$.

In 1902, to further explore the therapeutic potential of different dyes, Ehrlich and his Japanese colleague Kiyo- shi Shiga (1871-1957) undertook a systematic evaluation of hundreds of synthetic compounds in animal models of infection caused by protozoans. In 1904, their treatment with trypan red stain was successful in mice infected with Trypanosoma equinum. Unfortunately, some trypanosomes developed resistance to the dye and eventually killed the host animal. Experiments in other animals, such as rats and dogs, were likewise unsuccessful. Nevertheless, this work spurred Ehrlich's incessant search for compounds with antimicrobial properties, and he next turned to organic arsenic derivatives [4, 20,21].

Aminophenyl arsenic acid, better known by its commercial name Atoxyl ${ }^{\circledR}$ in allusion to its reduced toxicity compared to arsenic acid, had been synthesized in 1859 by the French biologist Pierre Jaques Antoine Béchamp (1816-1908) (fig. 3a). It was used in clinical practice in 1905 to treat African sleeping sickness (African trypanosomiasis). However, effective treatment required the use of high doses of the compound over a prolonged period, which entailed a high risk of blindness due to optic nerve atrophy. Ehrlich and his colleague Alfred Bertheim (1879-1914) (table 1), an organic chemist, were the first to determine the chemical structure of Atoxyl as an amino derivative of phenyl arsenic acid (fig. 3b); until that time it had been believed to be an arsenic acid anilide (fig. 3a). This new formula suggested other routes by which its chemical structure could be modified, and a number of derivatives were subsequently synthesized with the aim of enhancing its therapeutic efficacy $[4,5,9]$.

Upon adding substituents to the amino group of Atox$\mathrm{yl}$, they obtained compound No. 306 in their series: arsacetin or acetylatoxyl (fig. 3c). Although less toxic, when it was given at the high doses needed for treatment, mice began to move uncontrollably in circles because of damage to the vestibular nerve. This alteration, characteristic of Atoxyl, was a sign that arsacetin could also probably cause blindness. Moreover, Ehrlich observed that this compound was not effective in vitro, and he therefore assumed that these substances underwent modification in the organism and were thus converted into an activated form, as was also found years later with Prontosil ${ }^{\circledR}$, synthesized by Gerhard Domagk (1895-1964) [2]. By rigorously applying scientific method, Ehrlich formulated the hypothesis that these substances were activated by a reduction process. To test his hypothesis he asked Bertheim to obtain two potential types of reduction products artificially. One of them, the arsenic oxides or arsenoxides, were effective against trypanosomes but were highly toxic for the host. The second product, the arsenobenzenes, while not as potent as arsenoxides, proved to have fewer 
<smiles>O=[W](O)(O)Nc1ccccc1</smiles>

a<smiles>CC(=O)Nc1ccc(S(=O)(=O)O)cc1</smiles>

c<smiles>Oc1ccc(N=Nc2ccc(O)cc2)cc1</smiles><smiles>NC(=O)OCNc1cc(C=Nc2ccc(O)c(N)c2)ccc1O</smiles>

g

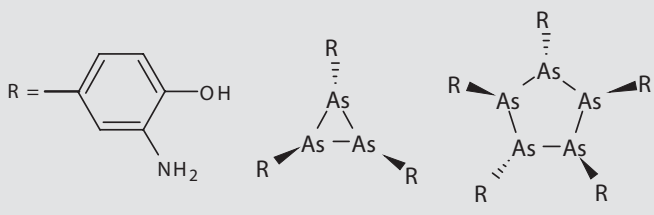

i

Fig. 3. Chemical structures of the main arsenical compounds directly related to Ehrlich's discoveries. a Original but incorrect structural formula of Atoxyl, according to Béchamp. b Correct formula of Atoxyl, aminophenylarsenic acid. c Arsacetin, acetylatoxyl, compound No. 306. d Spirarsyl, arsenophenylglycine, com-<smiles>Nc1ccc([As](=O)(O)(O)O)cc1</smiles>

b<smiles>O=C(O)CNc1ccc(N=Nc2ccc(NCC(=O)O)cc2)cc1</smiles><smiles>Nc1cc(C=Nc2ccc(O)c(N)c2)ccc1O</smiles>

f<smiles>Nc1cc(C=O)ccc1O</smiles>

h<smiles>Nc1nc(N)nc(Nc2ccc([As]3SCC(CO)S3)cc2)n1</smiles>

j 
toxic effects, and their administration at low doses circumvented the neurotoxicity problem. This limited set of substances became the centre of Ehrlich's attention. Specifically, it was compound No. 418, designated Spirasyl ${ }^{\circledR}$ or arsenophenylglycine, which turned out to be highly promising (fig. 3d). In addition to its trypanosomicidal effect and low toxicity in mice, it was also effective against spirochete infections. In 1907, this arsenobenzene was tested in humans with good results, except in a small group of patients who showed severe hypersensitivity reactions. Although in need of improvement, this compound was used to treat those trypanosomiases which had high mortality rates $[9,21]$.

Ehrlich obtained other derivatives of Atoxyl by adding a hydroxyl group at position 4 on the benzene ring. This process yielded arsenophenol (fig. 3e), a compound that was clearly effective against trypanosomes but with a propensity toward oxidation, and hard to purify. The addition of a substituent adjacent to the hydroxyl group led to arsphenamine or diaminodioxyarsenobenzol - compound No. 606 in his series (fig. 3f). This compound was synthesized in 1907, although Ehrlich's laboratory was unable to demonstrate its efficacy. It was not until 1909 when a reassessment of its pharmacological activity opened the door to chemotherapy for syphilis. As described below, Ehrlich and his colleagues had achieved the synthesis of the first man-made antibiotic, the first magic bullet Ehrlich so earnestly sought. These strategies bear witness to the fact that Ehrlich was the first to actually understand and take advantage of the idea, previously proposed by other authors, that chemical structure correlated with the activity shown by individual compounds $[9,11,13]$.

\section{Salvarsan ${ }^{\circledR}$, the First Successful Chemotherapeutic Drug}

In 1905, Fritz Schaudinn (1871-1906) and Erich Hoffmann (1868-1959) discovered that the Treponema pallidum spirochete was the causal agent of syphilis, a disease whose impact on society was comparable to that of AIDS today. Given the similarity between spirochetes and trypanosomes, Hoffmann suggested that Ehrlich use arsenical compounds to treat patients with syphilis. Upon the arrival at the laboratory of his Japanese student and colleague Sahachiro Hata (1873-1938) (fig. 1; table 1), who had been able to infect rabbits with syphilis, Ehrlich asked him to reassess all arsenicals synthesized until then. When he tested compound No. 606, Hata observed that it had truly notable curative properties against syphilis. Ehrlich had just discovered the magic bullet he had so intently been seeking: arsphenamine. This substance, consisting of about $30 \%$ arsenic, showed 'parasitotropic' properties but lacked 'organotropic' properties $[9,13,22-$ 24].

However, severe hypersensitivity problems in patients treated with arsenophenylglycine led the researchers to use extreme caution with arsphenamine. Only after the results of animal experiments had confirmed its safety and efficacy was it administered to patients. Soon afterwards, samples were sent to the Magdeburg Hospital and other centres for the first clinical trials in large numbers of patients with primary syphilis. On 19 April 1910, at the Congress for Internal Medicine at Wiesbaden, Ehrlich and Hata reported the discovery of arsphenamine and their encouraging preclinical and clinical results $[4,21$, 24]. Their announcement at this congress led to a large number of requests, which Ehrlich's institute fulfilled by dispensing 65,000 free samples so that further clinical trials could be done. Faced with the high demand worldwide, Hoechst marketed the drug under the name Salvarsan, 'the arsenic that saves'. This was the first truly effective drug against syphilis, and gained Ehrlich international recognition and popularity [14]. The enthusiasm with which the drug was received was reflected in newspaper headlines and scientific journals. Such was the popular impact that in 1940 Warner Brother Studios produced a feature film about Ehrlich titled Dr. Ehrlich's Magic Bullet $[9,16]$.

However, treatment of syphilis with arsenicals was prolonged and unpleasant. Combination therapy was necessary to destroy all spirochetes and thus prevent the appearance of resistance or disease recurrence. Periods during which the patient received intravenous infusions of arsphenamine alternated with mercury or bismuth treatment, which was used previously. The minimum treatment period lasted longer than 18 months and required 20 arsphenamine injections and 30-40 bismuth injections [25].

As was to be expected, the drug's undesirable effects soon appeared, and Ehrlich's detractors wasted no opportunity to renew their criticisms. The Russian Orthodox Church also opposed arsphenamine, based on the belief that venereal disease was a divine punishment for immorality and should not be treated. Moreover, problems arose with the galenic preparation of arsphenamide. Because it was insoluble in water and its hydrochloride form was too toxic for medical use, it required dilution in a basic solution before it could be administered. The need 
to find a water-soluble derivative that could be administered via injection favoured the synthesis, in 1914 - the year of Ehrlich's 60th birthday - of compound No. 914 or neoarsphenamine (fig. 3g) [22, 23]. Marketed under the name Neosalvarsan ${ }^{\circledR}$, it was an enhanced version of Salvarsan produced by binding arsphenamine to sodium bisulphite aldehyde; the resulting formulation shortened treatment times. Although it was less toxic, containing only $19 \%$ arsenic [2], neoarsphenamine was nonetheless associated with side-effects such as nausea and vomiting. An additional problem was that both Salvarsan and Neosalvarsan had to be stored in sealed vials under a nitrogen atmosphere to prevent oxidation [26].

During World War I, arsenicals became scarce as a result of the German blockade, their price increased, and cases of fraud occurred. In the USA, the patents protecting arsphenamines were suspended, and several US laboratories began to produce these compounds to treat syphilis [27].

Although Salvarsan and Neosalvarsan became established as the standard treatments for syphilis, research on arsenicals continued. In 1930, it was discovered that arsphenamine, once administered, was oxidized to oxophenarsine (marketed under the name Mapharsen ${ }^{\circledR}$; fig. $3 \mathrm{~h}$ ), and this metabolite was in fact the active compound. Because of its stability, it became the drug of choice for the treatment of syphilis until penicillin was introduced in 1940. Oddly, this compound had already been synthesized at Ehrlich's laboratory, where it was listed as compound No. 599 but neglected because of its presumably high toxicity [9].

The structure of arsphenamine was also a subject of debate from the moment the drug was introduced. Ehrlich and his contemporaries believed that arsenobenzenes, like azobenzenes, consisted of two molecules joined by a double bond between their corresponding arsenic atoms. However, years later Ehrlich's assumption was shown to be incorrect, and it was recognized that arsenobenzenes were actually polymers formed by hundreds of molecules whose arsenic atoms were joined by single bonds $[16,28]$. A more recent study published by Lloyd et al. [29] showed, with ionization mass spectrometry, that neither arsphenamine nor neoarsphenamine were pure substances but were instead mixtures of arsenic trimers and pentamers. Their structure was therefore based on rings and single bonds between arsenic atoms, rather than the common double bond form described by Ehrlich (fig. 3i).

\section{The Path toward the Development of Antibiotics}

Ehrlich often said that to achieve success one needed the four Gs (in German): Geld ('money'), Geduld ('patience'), Geschick ('intelligence') and Glück ('luck'). Upon being congratulated on the success of Salvarsan he often replied: 'For seven years of misfortune I had one moment of good luck' $[5,23,30]$. Paul Ehrlich was a hard-working, kind, modest man with a sense of humour. At work he was energetic, enthusiastic and bold, while insisting on checking and rechecking the results of his experiments. He was a perfectionist with a prodigious capacity for deduction, which combined an exacting methodological approach with anarchic tendencies. This combination gave rise to a personality that some have ventured to describe as that of a genius. Although he unfailingly earned the respect of those around him, his health was not robust, he ate little, and smoked heavily. Years after his recovery from tuberculosis, which he suffered at the age of 24, he survived a first stroke in 1914. On 20 August 1915, at the age of 61 , he suffered a second, fatal stroke [1,23].

Ehrlich's work was recognized with ten honorary doctorates and the Prussian Great Gold Medal for Science (1903), awarded previously only to Rudolf Virchow. He was named Full Honorary Professor of the University of Göttingen (1904), and was appointed Privy Councillor to the government of Prussia, with the right to be addressed as 'Your Excellency' (1911). After receiving the Nobel Prize in 1908, he was nominated again in 1912 and 1913 for his contributions to chemotherapy. However, it was still too soon for Salvarsan to be seen as the first great triumph in the synthesis of chemotherapeutic agents. These honours notwithstanding, all recognition he received during that period and after his death fell short of his merits, especially in Germany, owing to his Jewish parentage $[23,31,32]$.

More than 100 years ago, Ehrlich recognized the need to combat infectious diseases by designing selective drugs. He established the concept of the 'chemotherapeutic index' as the quotient of the minimum effective dose divided by the maximum tolerated dose, and discovered that microorganisms could acquire drug resistance $[6$, 19]. The expressions corpora non agunt nisi fixata ('drugs will not act unless they are bound') and therapia sterilisans magna, mentioned above, became the cornerstones upon which he built his pharmacological strategy $[3,19]$. His working methods were undoubtedly a model for obtaining new synthetic compounds. And although the search for new drugs against protozoan-caused diseases was productive, scant progress was made in the treatment 
of bacterial diseases. As a result, the 20 years following his death became known as the 'doldrum years' of chemotherapy - in other words, a period barren of therapeutic success [6]. An excellent review published in 2004 by Jürgen Drews to celebrate the 150th anniversary of Ehrlich's birth offers a detailed look into many scientific and personal aspects of his life [23].

The antibiotic revolution sparked by arsphenamine was followed by the discovery of Prontosil by Domagk in 1932. Sulphonamides were proof that Ehrlich was right: dyes could act as antibacterial agents. With the appearance of penicillin as a result of work by Alexander Fleming (1881-1955), Howard Florey (1898-1968) and Ernst Boris Chain (1906-1979), arsenicals were gradually superseded but did not disappear entirely $[24,31]$. To this day, the injectable arsenic derivative melarsoprol (Arso- bal $^{\circledR}$ ) (fig. 3j) remains in use as the treatment of choice for sleeping sickness.

Trained as a physician, Ehrlich can be considered on the basis of his research career as an organic chemist, histologist, haematologist, immunologist or pharmacologist without distinction - or a giant among giants $[6,33]$. Despite the scope of his many achievements in different disciplines, Paul Ehrlich's name will undoubtedly remain linked to Salvarsan and the birth of chemotherapy.

\section{Acknowledgments}

The authors thank Sergio Erill for his review of and suggestions for improving the manuscript. We also thank K. Shashok for translating the original manuscript into English.

\section{References}

1 Official Website of the Nobel Foundation Stockholm, 2008. http://nobelprize.org (accessed May 5, 2008).

2 Rubin RP: A brief history of great discoveries in pharmacology: in celebration of the centennial anniversary of the founding of the American Society of Pharmacology and Experimental Therapeutics. Pharmacol Rev 2007;59:289-359.

3 Kaufmann SHE: Paul Ehrlich: founder of chemotherapy. Nat Rev Drug Discov 2008;7: 373.

4 Silverman M: Kill the Germs! Lister to Ehrlich to 205. Magic in a Bottle. New York, MacMillan, 1942, pp 134-168.

5 Mann J: The Elusive Magic Bullet. The Search for the Perfect Drug. New York, Oxford University Press, 1999, pp 1-209.

6 Kasten FH: Paul Ehrlich: pathfinder in cell biology. 1. Chronicle of his life and accomplishments in immunology, cancer research, and chemotherapy. Biotech Histochem 1996; $71: 2-37$

7 Venita J: A portrait of history: Paul Ehrlich. Arch Pathol Lab Med 2001;125:724.

-8 Crivellato E, Beltrami CA, Mallardi F, Ribatti D: Paul Ehrlich's doctoral thesis: a milestone in the study of mast cells. Br J Haematol 2003;123:19-21.

-9 Riethmiller S: From Atoxyl to Salvarsan: searching for the magic bullet. Chemotherapy $2005 ; 51: 234-242$.

10 Paul Ehrlich. Langen, Paul-Ehrlich-Institut. http://www.pei.de/cln_046/nn_162438/EN/ institute-en/paul-ehrlich-en/paul-ehrlichnode-en.html?_nnn=true (accessed May 5, 2008).
11 Parascandola J: The theoretical basis of Paul Ehrlich's chemotherapy. J Hist Med Allied Sci 1981;36:19-43.

12 Kristiansen JE: Dyes, antipsychotic drugs, and antimicrobial activity. Fragments of a development, with special reference to the influence of Paul Ehrlich. Dan Med Bul 1989;36:178-185.

13 Winau F, Westphal O, Winau R: Paul Ehrlich - In search of the magic bullet. Microbes Infect 2004;6:786-789.

14 Schwartz RS: Paul Ehrlich's magic bullets. N Engl J Med 2004;350:1079-1080.

15 Weatheral M: In Search of a Cure. New York, Oxford University Press, 1999.

16 Witkop B: Paul Ehrlich and his magic bullets - Revisited. Proc Am Philos Soc 1999; 143:540-557.

17 Bennett MR: The concept of transmitter receptors: 100 years on. Neuropharmacology 2000;39:523-546.

18 Akatsu S, Noguchi H: The drug-fastness of spirochetes to arsenic, mercurial, and iodide compounds in vitro. J Exp Med 1917;25:349_ 362.

19 Krantz JC Jr: Paul Ehrlich and 'The Magic Bullet', Arsphenamine. Historical Medical Classics Involving New Drugs. Baltimore, Williams \& Wilkins, 1974, pp 51-57.

20 Felsenfeld O: K. Shiga, bacteriologist. Science 1957;126:113.

21 Sneader W: Drug Discovery: A History. Chichester, Wiley, 2005.
22 Jolliffe DM: A history of the use of arsenicals in man. J R Soc Med 1993;86:287-289.

23 Drews J: Paul Ehrlich: magister mundi. Nat Rev Drug Discov 2004;3:797-801.

24 Gensini GF, Conti AA, Lippi D: The contributions of Paul Ehrlich to infectious disease. J Infect 2007;54:221-224

25 Marlow FW Jr: Syphilis then and now. JAMA 1974;230:1320-1321.

26 Jaouen G, Beck W, McGlinchey MJ: A Novel Field of Research: Bioorganometallic Chemistry, Origins, and Founding Principles. Weinheim, Wiley-VCH, 2006, pp 1-37.

27 Montes J, Cueva J: Ehrlich, su vida y su obra. Alergia 1967;15:29-42.

28 Cowley AH, Lasch JG, Norman NC, Pakulski M: Synthesis and structure of a diarsene: the first compound with an unsupported arsenic-arsenic double bond. J Am Chem Soc 1983; 105:5506-5507.

-29 Lloyd NC, Morgan H, Nicholson BK, Ronimus RS: The composition of Ehrlich's salvarsan: resolution of a century-old debate. Angew Chem Int Ed Engl 2005;44:941-944.

30 Raju TNK: The Nobel chronicles. 1908: Elie Metchnikoff (1845-1916), Paul Ehrlich (1854-1915). Lancet 1998;352:661.

31 Jacobs MS: Paul Ehrlich and his relation to modern chemotherapy. Bull Hist Med 1940; 8:956-964.

32 Silverstein AM: Paul Ehrlich, archives and the history of immunology. Nat Immunol 2005;6:639.

33 Cowen DL, Segelman AB: Antibiotics in Historical Perspective. New Jersey, Merck Sharp \& Dohme, 1981. 